\title{
Nephrotoxicity of Cis-Platin Comparing Young and Adult Rats
}

\author{
H. T. M. JONGEJAN, A. P. PROVOOST, E. D. WOLFF, AND J. C. MOLENAAR \\ Department of Pediatric Surgery and Pediatrics, Erasmus University Medical School, \\ Rotterdam, The Netherlands
}

\begin{abstract}
The effect of Cis-platin on the glomerular filtration rate and effective renal plasma flow was determined using a radioisotope clearance technique in young (3 wk old) and adult (more than 12 wk old) rats. Cis-platin was administered intravenously in dosages ranging from 2.5 to $10 \mathrm{mg} / \mathrm{kg}$ body weight, either as a single dose or fractionated over 5 consecutive days. Following either dose regimen, identical total doses of Cis-platin caused less severe nephrotoxicity in young rats than in adult ones. In adult rats fractionated dosage significantly reduced nephrotoxicity. This was not observed in young rats. The difference in nephrotoxicity between young and adult rats was due to the renal handling of Cis-platin. After a single dose of 5 and $7.5 \mathrm{mg} / \mathrm{kg}$ body weight, platinum concentrations were measured in urine and renal tissue. During the first 2 days after Cis-platin administration, up to $60 \%$ of the amount of platinum injected was excreted in the urine of both age groups. There was a marked difference, however, in renal platinum concentration between the two groups. In young rats renal platinum concentration was only 63 and $49 \%$ of that in adult rats after 5 and $7.5 \mathrm{mg} / \mathrm{kg}$ body weight, respectively. We believe that this is due to the comparatively larger renal mass in relation to body weight in the young animals. Relatively more renal tissue provides at least partial protection against nephrotoxic drugs in these young rats. (Pediatr Res 20: 9-14, 1986)
\end{abstract}

\section{Abbreviations}

BW, body weight

ERPF, effective renal plasma flow

GFR, glomerular filtration rate

iv, intravenous

Pt, platinum

Cis-platin (Cis-diamminedichloroplatinum, abbreviated as CDDP) has been proven to be a valuable agent in adult oncologic therapy and is increasingly used in pediatric oncology (1-3). Animal $(4,5)$ as well as clinical $(6-8)$ studies have demonstrated that therapeutic dosage leads to nephrotoxicity. This side effect may in fact be dose limiting $(4,9)$. The nephrotoxicity can be alleviated but not entirely prevented by good hydration, forced diuresis, and prolonged administration $(7,8,10)$.

It has been suggested that the incidence of nephrotoxicity in children is less than in adults (11). Clinical and experimental

Received February 25, 1985; accepted August 14, 1985

Correspondence to A. P. Provoost, Department of Pediatric Surgery, Laboratory for Surgery, Erasmus University Rotterdam, PB 1738, 3000 DR Rotterdam, The Netherlands.

This study was supported by a grant from the Dutch Cancer Foundation (Koningin Wilhelmina Fonds). data substantiating this statement are scarce. In the present study we compared, GFR and ERPF of young and adult rats after various doses of Cis-platin. We also evaluated the renal handling of this drug by measuring urinary excretion and renal accumulation of $\mathrm{Pt}$.

\section{MATERIALS AND METHODS}

Experiments were carried out using male rats of an outbred wistar strain (WU/CPB, TNO Zeist, The Netherlands). The animals were selected according to BW and age. The young rats were 3-4 wk of age weighing 50-65 g, the adult rats were more than 12 wk of age, weighing 270-340 g. Tap water and food were available at libitum.

Renal function determination. The GFR and the ERPF were determined by a plasma clearance technique, as described in detail elsewhere (12). This method involves iv injection of $\mathrm{Cr}-51$ EDTA and I-125 Iodohippurate (Amersham International, Amersham, England) and a single timed blood sample collected 60 min after the injection. The method allows for repeated use in the same animal.

Pt determination. The $\mathrm{Pt}$ content of urine and renal tissue was determined by atomic absorption spectrophotometry using a Perkin Elmer 2380 spectrophotometer. The urine samples were analyzed without pretreatment and read against a standard curve based on aqueous standards. The kidneys were weighed, freeze dried, and digested in $65 \% \mathrm{HN03}$ at $200^{\circ} \mathrm{C}$ in $1.5-2 \mathrm{~h}$. Ptstandards were added to control kidneys which were similarly treated. The dry residue was then dissolved in $2 \mathrm{ml}$ of distilled water, and analyzed.

Experimental Protocol. Single dosage regimen. Cis-platin (kindly supplied by Bristol Meyers BV, Weesp, The Netherlands) was diluted with distilled water to a final concentration of $1 \mathrm{mg}$ Cis-platin, $9 \mathrm{mg} \mathrm{NaCl}$, and $10 \mathrm{mg}$ mannitol per $\mathrm{ml}$.

Cis-platin was administered iv in a dose of $2.5,5$, or $7.5 \mathrm{mg} /$ $\mathrm{kg} \mathrm{BW}$ in adult rats and $5,7.5$, or $10 \mathrm{mg} / \mathrm{kg} \mathrm{BW}$ in the young animals. The highest dose was determined by the $100 \%$ mortality rate for both age groups. Control animals were given iv injections of distilled water. At the start of the experiments the groups consisted of five to 15 rats.

Renal function was determined $4,7,14,21,42$, and 105 days after drug administration.

Fractionated dose regimen. In this regimen the total amount of Cis-platin was administered iv in equal doses over 5 successive days. The total dosage was the same for adult and young rats, viz $5 \times 1,5 \times 1.5$, or $5 \times 2 \mathrm{mg} / \mathrm{kg} \mathrm{BW}$. Control animals were given 5 daily iv injections of distilled water. At the start of the experiment the groups consisted of five to 10 rats.

Renal function was determined 7, 10, 17, 24, 42, and 105 days after the first drug administration.

Renal Pt handling. In seven young and eight adult rats, the urinary excretion and the renal accumulation of Pt were determined after a single iv injection of Cis-platin in a dose of 5 or 
$7.5 \mathrm{mg} / \mathrm{kg} \mathrm{BW}$. Urine was collected for 2 days. Subsequently, the kidneys were removed and weighed. Both, urine and renal tissue were analyzed for Pt.

Statistics. Data are recorded as mean and SD. Within each age group differences in means of either GFR or ERPF values comparing the various treatment groups and controls were established by one way analysis of variance. When a difference was indicated $(p<0.05)$, the Newman-Keuls test was applied to determine which pair(s) of groups were statistically different. Student's $t$ test was applied to establish significant differences between young and adult rats regarding renal Pt handling and the GFR after the same dosage regimens. Statistical difference was indicated by a $p$ value of $<0.05$.

\section{RESULTS}

Single Dosage Regimen. Adult animals. The adult animals showed marked weight loss in the first days after Cis-platin administration (Table 1). Particularly after doses amounting to $7.5 \mathrm{mg} / \mathrm{kg} \mathrm{BW}$, the rats suffered from anorexia and diarrhea. The animals receiving this dose all died on the 4th day after Cisplatin administration with little residual function. The lower doses of Cis-platin resulted in a dose-dependent fall in both GFR and ERPF, the lowest value being measured 4 days after drug administration. After this initial fall there was recovery during the next 3 wk (Table 1). Subsequently, renal function stabilized. With $5 \mathrm{mg} / \mathrm{kg} \mathrm{BW}$ the GFR initially fell to $10 \%$ of the control value and recovered to $50-60 \%$ of control after 15 wk. After 2.5 $\mathrm{mg} / \mathrm{kg} \mathrm{BW}$ the initial fall in GFR was $40 \%$ and subsequent recovery was complete.

Young rats. The young rats failed to grow during the first days after drug administration but resumed gaining weight after $1 \mathrm{wk}$. As a result dose-dependent differences in BW were observed and remained statistically different up to the 6th wk (Table 2). Young rats treated with $10 \mathrm{mg} / \mathrm{kg} \mathrm{BW}$ all died in the 1 st wk following administration. When expressed in $\mathrm{ml} / \mathrm{min}$ the GFR was significantly less in young rats treated with Cis-platin than in controls. As both GFR and BW were reduced, the GFR per $100 \mathrm{~g} \mathrm{BW}$ showed little difference in rats treated with 5 or $7.5 \mathrm{mg} / \mathrm{kg} \mathrm{BW}$ when compared to the control rats.

Comparison between young and adult rats. In the single dose regimen, a dose of 5 and $7.5 \mathrm{mg} / \mathrm{kg} \mathrm{BW}$ was administered to both young and adult rats. When the initial changes in renal function were compared (expressed as percentage of the controls), the fall in GFR was less in the young rats than in the adult ones. This was true not only when the GFR was related to BW (ml/ $\mathrm{min} / 100 \mathrm{~g} \mathrm{BW}$ ) (Fig. 1) but also when absolute values (ml/min) were taken into consideration (Tables 1 and 2). Furthermore, renal function remained permanently reduced in the adult rats, while there was complete recovery in the young ones.

Fractionated Dosage Regimen. Adult rats. The weight loss observed during the first 2 wk after drug administration was comparable with the weight loss after corresponding single doses. However, fractionation did reduce the mortality rate and immediate nephrotoxicity (Table 3 ). All animals survived after $5 \times$ $1.5 \mathrm{mg} / \mathrm{kg} \mathrm{BW}$, while only $50 \%$ died during the first 3 wk after a dose of $5 \times 2 \mathrm{mg} / \mathrm{kg} \mathrm{BW}$. The initial impairment in renal function was less severe after $5 \times 1 \mathrm{mg} / \mathrm{kg} \mathrm{BW}$ than after $1 \times 5$ $\mathrm{mg} / \mathrm{kg} \mathrm{BW}$. However, at the end of the $15 \mathrm{wk}$ follow-up period the renal impairment was similar after either dosage regimens.

Young rats. Fractionation caused a growth retardation similar to that observed after a single dose when $5 \mathrm{mg} / \mathrm{kg} \mathrm{BW}$ was administered. With $7.5 \mathrm{mg} / \mathrm{kg} \mathrm{BW}$, the growth reduction was less when given fractionated than after a single dose (Tables 2 and 4). The GFR $(\mathrm{ml} / \mathrm{min})$ of rats treated with Cis-platin was less than that of controls. However, the GFR relative to body weight $(\mathrm{ml} / \mathrm{min} / 100 \mathrm{~g})$ showed little difference from control values. After fractionated dosage of Cis-platin the GFR was generally comparable to the GFR after an identical single dose.

Comparison between Young and Adult Rats. In the young rats,

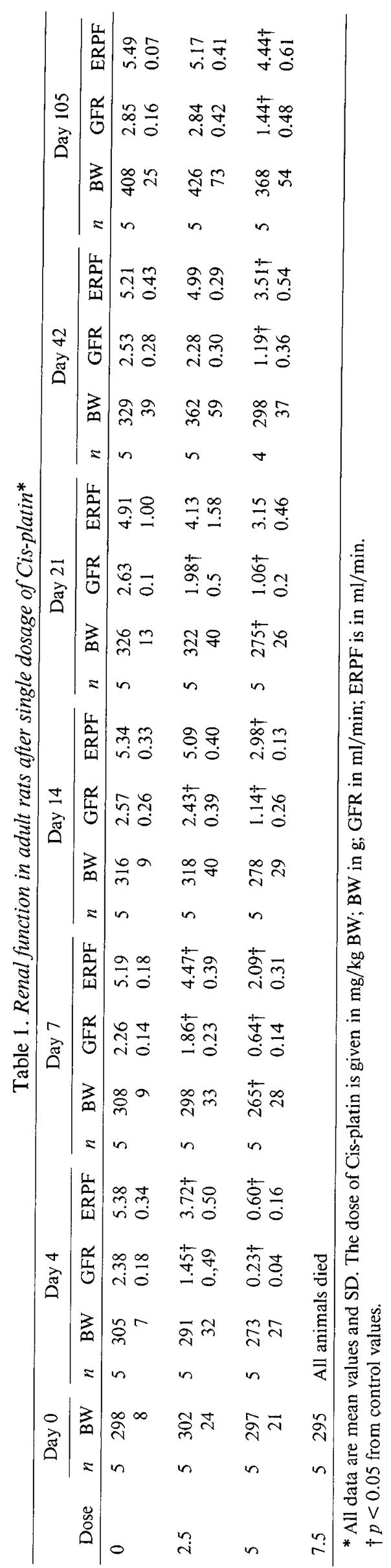




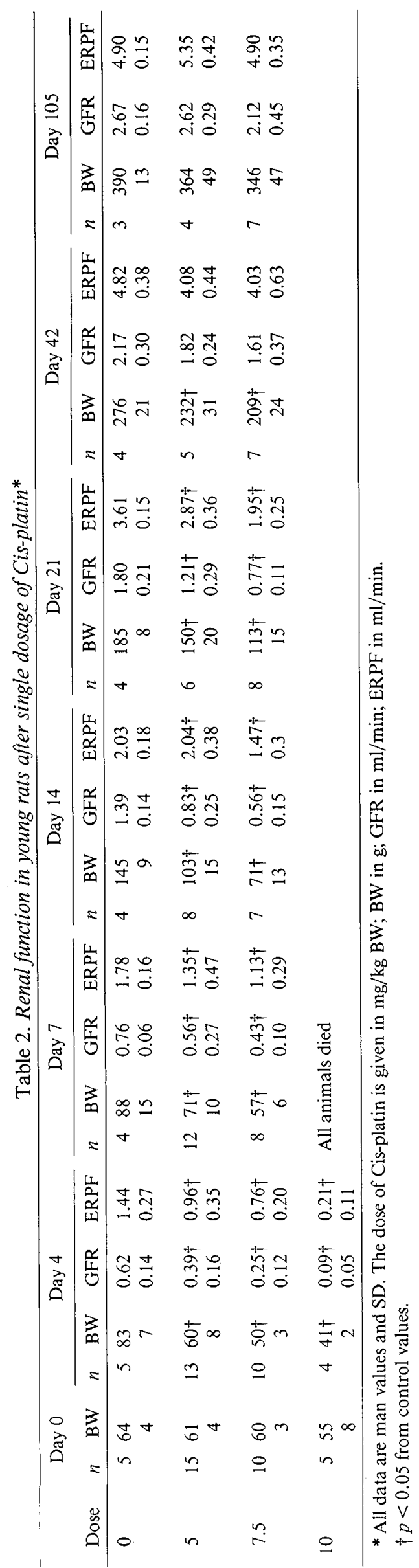

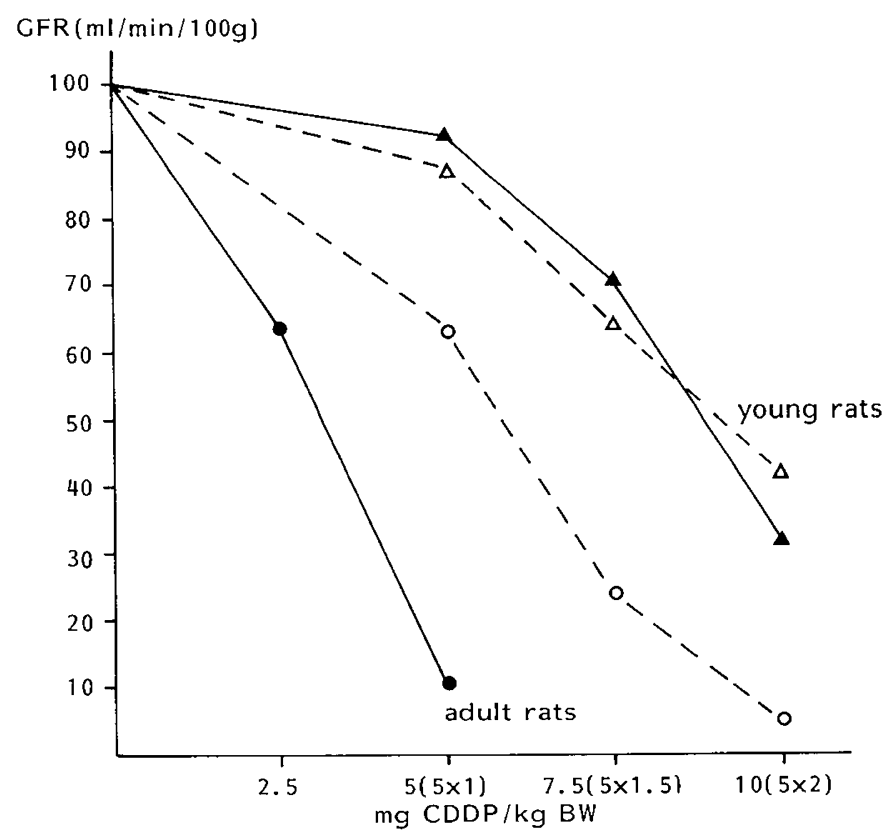

Fig. 1. Comparison of the initial changes in GFR of either young or adult rats treated with Cis-platin. The GFR ( $\mathrm{ml} / \mathrm{min} / 100 \mathrm{~g} \mathrm{BW})$ is given as a percentage of that of control rats, on day 4 after the first administration of Cis-platin for the single dose and day 7 after the first administration for the fractionated dosage regimen. Solid lines and closed symbols represent single dosage, broken lines and open symbols represent fractionated dosage. Circles represent adult rats and triangles represent young rats.

renal function was less affected by the same dose of Cis-platin given fractionated than in adult animals. The GFR per $100 \mathrm{~g}$ $\mathrm{BW}$, as percentage of the mean value in controls, was determined on day 4 after drug administration and is plotted against the total dose of Cis-platin. As shown in Figure 1, the dose response curve for the adult rats is much steeper than for young rats. This difference remained at the end of the 15 wk follow-up period (Fig. 2).

Renal Pt Handling. During the first 2 days after a single dose of $5 \mathrm{mg}$ Cis-platin per $\mathrm{kg} \mathrm{BW}$ about $60 \%$ of the administered amount of Pt was excreted in the urine of young as well as adult rats. After $7.5 \mathrm{mg}$ Cis-platin per $\mathrm{kg} \mathrm{BW}$ the young rats excreted relatively more $\mathrm{Pt}$ than the adult rats (Table 5). Most of the $\mathrm{Pt}$ was excreted during the 1 st day after administration. After 2 days both Cis-platin doses caused a similar Pt accumulation in young and adult rats of $1.5-2 \%$ of the injected amount of Pt. However, the renal Pt concentration was significantly lower in the young rats compared to the adult rats (Table 5). This was due to the larger renal mass relative to BW in the young rats. As shown in Table 5 the wet kidney weight per $100 \mathrm{~g} \mathrm{BW}$ of young rats was 179 and $165 \%$ of that of adult rats in the 5 and $7.5 \mathrm{mg}$ dose group, respectively.

\section{DISCUSSION}

Our study has shown that an identical dose of Cis-platin per $\mathrm{kg} \mathrm{BW}$ administered to either young or adult rats, leads to a deterioration of renal function which is comparatively less severe in young rats. In both young and adult rats the deterioration in renal function occurs during the initial days after Cis-platin administration with gradual recovery during the following weeks. Complete recovery is more likely to occur in young rats with a higher degree of permanent damage in adult rats. In young rats Cis-platin temporarily arrests body growth and renal development, but this does not affect the potential for growth and development. The initial impairment in renal function of young 
Table 3. Renal function in adult rats after fractionated dosage of Cis-platin*

\begin{tabular}{|c|c|c|c|c|c|c|c|c|c|c|c|c|c|c|c|c|c|c|c|c|c|c|c|c|c|c|}
\hline \multirow[b]{2}{*}{ Dose } & \multicolumn{2}{|c|}{ Day 0} & \multicolumn{4}{|c|}{ Day 7} & \multicolumn{4}{|c|}{ Day 10} & \multicolumn{4}{|c|}{ Day 17} & \multicolumn{4}{|c|}{ Day 24} & \multicolumn{4}{|c|}{ Day 42} & \multicolumn{4}{|c|}{ Day 105} \\
\hline & $n$ & BW & $n$ & BW & GFR & ERPF & $n$ & BW & GFR & ERPF & $n$ & BW & GFR & ERPF & $n$ & BW & GFR & ERPF & $n$ & BW & GFR & ERPF & $n$ & BW & GFR & ERPF \\
\hline $5 \times 0$ & 5 & $\begin{array}{r}319 \\
17\end{array}$ & 5 & $\begin{array}{r}325 \\
21\end{array}$ & $\begin{array}{l}2.17 \\
0.28\end{array}$ & $\begin{array}{l}4.67 \\
0.57\end{array}$ & 5 & $\begin{array}{r}327 \\
22\end{array}$ & $\begin{array}{l}2.41 \\
0.14\end{array}$ & $\begin{array}{l}5.22 \\
0.29\end{array}$ & 4 & $\begin{array}{r}339 \\
24\end{array}$ & $\begin{array}{l}2.50 \\
0.23\end{array}$ & $\begin{array}{l}4.37 \\
0.22\end{array}$ & 4 & $\begin{array}{r}345 \\
28\end{array}$ & $\begin{array}{l}2.46 \\
0.21\end{array}$ & $\begin{array}{l}4.96 \\
0.18\end{array}$ & 4 & $\begin{array}{r}379 \\
44\end{array}$ & $\begin{array}{l}3.15 \\
0.34\end{array}$ & $\begin{array}{l}5.84 \\
0.31\end{array}$ & 4 & $\begin{array}{r}434 \\
54\end{array}$ & $\begin{array}{l}2.90 \\
0.37\end{array}$ & $\begin{array}{l}5.42 \\
0.13\end{array}$ \\
\hline $5 \times 1$ & 5 & $\begin{array}{r}292 \\
15\end{array}$ & 5 & $\begin{array}{c}261 \dagger \\
12\end{array}$ & $\begin{array}{l}1.12 \dagger \\
0.32\end{array}$ & $\begin{array}{l}3.05 \dagger \\
0.48\end{array}$ & 5 & $\begin{array}{c}268 \dagger \\
14\end{array}$ & $\begin{array}{l}1.32 \dagger \\
0.10\end{array}$ & $\begin{array}{l}3.73 \dagger \\
0.44\end{array}$ & 5 & $\begin{array}{c}278 \dagger \\
17\end{array}$ & $\begin{array}{l}1.58 \dagger \\
0.24\end{array}$ & $\begin{array}{l}4.38 \\
0.32\end{array}$ & 5 & $\begin{array}{c}291 \dagger \\
14\end{array}$ & $\begin{array}{l}1.57 \dagger \\
0.26\end{array}$ & $\begin{array}{l}4.36 \\
0.34\end{array}$ & 4 & $\begin{array}{c}320 \dagger \\
13\end{array}$ & $\begin{array}{l}1.70 \dagger \\
0.38\end{array}$ & $\begin{array}{l}4.15 \dagger \\
0.32\end{array}$ & 3 & $\begin{array}{c}360 \dagger \\
11\end{array}$ & $\begin{array}{l}2.09 \dagger \\
0.38\end{array}$ & $\begin{array}{l}4.95 \\
0.20\end{array}$ \\
\hline $5 \times 1.5$ & 5 & $\begin{array}{r}262 \\
19\end{array}$ & 5 & $\begin{array}{c}245 \dagger \\
19\end{array}$ & $\begin{array}{l}0.39 \dagger \\
0.19\end{array}$ & $\begin{array}{l}1.92 \dagger \\
0.55\end{array}$ & 5 & $\begin{array}{c}237 \dagger \\
20\end{array}$ & $\begin{array}{l}0.55 \dagger \\
0.34\end{array}$ & $\begin{array}{l}2.00 \dagger \\
0.68\end{array}$ & 5 & $\begin{array}{c}216 \dagger \\
26\end{array}$ & $\begin{array}{l}0.76 \dagger \\
0.31\end{array}$ & $\begin{array}{l}2.43 \dagger \\
0.8\end{array}$ & 5 & $\begin{array}{c}254 \dagger \\
23\end{array}$ & $\begin{array}{l}0.78 \dagger \\
0.29\end{array}$ & $\begin{array}{l}3.16 \dagger \\
0.70\end{array}$ & 5 & $\begin{array}{c}290 \dagger \\
30\end{array}$ & $\begin{array}{l}0.90 \dagger \\
0.38\end{array}$ & $\begin{array}{l}3.36 \dagger \\
0.86\end{array}$ & 5 & $\begin{array}{c}330 \dagger \\
29\end{array}$ & $\begin{array}{l}1.11 \dagger \\
0.44\end{array}$ & $\begin{array}{l}3.91 \\
1.13\end{array}$ \\
\hline $5 \times 2$ & 10 & $\begin{array}{r}287 \\
19 \\
\end{array}$ & 9 & $\begin{array}{c}249 \dagger \\
21 \\
\end{array}$ & $\begin{array}{l}0.11 \dagger \\
0.11\end{array}$ & $\begin{array}{l}0.74 \dagger \\
0.58 \\
\end{array}$ & 8 & $\begin{array}{c}225 \dagger \\
18 \\
\end{array}$ & $\begin{array}{l}0.13 \dagger \\
0.15 \\
\end{array}$ & $\begin{array}{l}0.73 \dagger \\
0.66 \\
\end{array}$ & 5 & $\begin{array}{c}243 \dagger \\
21 \\
\end{array}$ & $\begin{array}{l}0.25 \dagger \\
0.20\end{array}$ & $\begin{array}{l}1.01 \dagger \\
0.35 \\
\end{array}$ & 5 & $\begin{array}{c}245 \dagger \\
35 \\
\end{array}$ & $\begin{array}{l}0.32 \dagger \\
0.23 \\
\end{array}$ & $\begin{array}{l}1.19 \dagger \\
0.91\end{array}$ & 5 & $\begin{array}{c}278 \dagger \\
33 \\
\end{array}$ & $\begin{array}{l}0.32 \dagger \\
0.22 \\
\end{array}$ & $\begin{array}{l}1.37 \dagger \\
1.00\end{array}$ & 3 & $\begin{array}{c}314 \dagger \\
35\end{array}$ & $\begin{array}{l}0.31 \dagger \\
0.19\end{array}$ & $\begin{array}{l}1.40 \dagger \\
0.86\end{array}$ \\
\hline
\end{tabular}

$\dagger p<0.05$ from control values.

Table 4. Renal function in young rats after fractionated dosage of Cis-platin *

\begin{tabular}{|c|c|c|c|c|c|c|c|c|c|c|c|c|c|c|c|c|c|c|c|c|c|c|c|c|c|c|}
\hline \multirow[b]{2}{*}{ Dose } & \multicolumn{2}{|c|}{ Day 0} & \multicolumn{4}{|c|}{ Day 7} & \multicolumn{4}{|c|}{ Day 10} & \multicolumn{4}{|c|}{ Day 17} & \multicolumn{4}{|c|}{ Day 24} & \multicolumn{4}{|c|}{ Day 42} & \multicolumn{4}{|c|}{ Day 105} \\
\hline & $n$ & BW & $n$ & BW & GFR & ERPF & $n$ & BW & GFR & ERPF & $n$ & BW & GFR & ERPF & $n$ & BW & GFR & ERPF & $n$ & BW & GFR & ERPF & $n$ & BW & GFR & ERPF \\
\hline $5 \times 0$ & 5 & $\begin{array}{r}53 \\
3\end{array}$ & 5 & $\begin{array}{r}79 \\
4\end{array}$ & $\begin{array}{l}0.72 \\
0.10\end{array}$ & $\begin{array}{l}1.74 \\
0.12\end{array}$ & 5 & $\begin{array}{r}92 \\
6\end{array}$ & $\begin{array}{l}0.77 \\
0.13\end{array}$ & $\begin{array}{l}1.90 \\
0.05\end{array}$ & 5 & $\begin{array}{r}135 \\
9\end{array}$ & $\begin{array}{l}1.22 \\
0.12\end{array}$ & $\begin{array}{l}2.33 \\
0.25\end{array}$ & 5 & $\begin{array}{r}167 \\
11\end{array}$ & $\begin{array}{l}1.69 \\
0.23\end{array}$ & $\begin{array}{l}3.53 \\
0.15\end{array}$ & 5 & $\begin{array}{r}257 \\
21\end{array}$ & $\begin{array}{l}2.11 \\
0.24\end{array}$ & $\begin{array}{l}4.64 \\
0.26\end{array}$ & 4 & $\begin{array}{r}356 \\
37\end{array}$ & $\begin{array}{l}2.53 \\
0.41\end{array}$ & $\begin{array}{l}5.50 \\
0.45\end{array}$ \\
\hline $5 \times 1$ & 10 & $\begin{array}{r}54 \\
4\end{array}$ & 8 & $\begin{array}{c}57 \dagger \\
8\end{array}$ & $\begin{array}{l}0.46 \dagger \\
0.17\end{array}$ & $\begin{array}{l}1.09 \dagger \\
0.29\end{array}$ & 5 & $\begin{array}{c}76 \dagger \\
5\end{array}$ & $\begin{array}{l}0.77 \\
0.15\end{array}$ & $\begin{array}{l}1.72 \\
0.21\end{array}$ & 9 & $\begin{array}{c}103 \dagger \\
16\end{array}$ & $\begin{array}{l}0.83 \dagger \\
0.30\end{array}$ & $\begin{array}{l}1.86 \dagger \\
0.50\end{array}$ & 7 & $\begin{array}{r}133 \\
25\end{array}$ & $\begin{array}{l}1.17 \dagger \\
0.37\end{array}$ & $\begin{array}{l}2.63 \dagger \\
0.52\end{array}$ & 7 & $\begin{array}{r}226 \\
27\end{array}$ & $\begin{array}{l}1.84 \\
0.37\end{array}$ & $\begin{array}{l}3.85 \\
0.30\end{array}$ & 7 & $\begin{array}{r}347 \\
49\end{array}$ & $\begin{array}{l}2.50 \\
0.34\end{array}$ & $\begin{array}{l}5.38 \\
0.63\end{array}$ \\
\hline $5 \times 1.5$ & 10 & $\begin{array}{r}60 \\
8\end{array}$ & 7 & $\begin{array}{c}56 \dagger \\
6\end{array}$ & $\begin{array}{l}0.33 \dagger \\
0.06\end{array}$ & $\begin{array}{l}0.86 \dagger \\
0.23\end{array}$ & 7 & $\begin{array}{c}66 \dagger \\
5\end{array}$ & $\begin{array}{l}0.42 \dagger \\
0.11\end{array}$ & $\begin{array}{l}1.28 \dagger \\
0.25\end{array}$ & 7 & $\begin{array}{c}100 \dagger \\
7\end{array}$ & $\begin{array}{l}0.54 \dagger \\
0.16\end{array}$ & $\begin{array}{l}1.54 \dagger \\
0.24\end{array}$ & 7 & $\begin{array}{c}127 \dagger \\
15\end{array}$ & $\begin{array}{l}0.92 \dagger \\
0.30\end{array}$ & $\begin{array}{l}2.39 \dagger \\
0.35\end{array}$ & 7 & $\begin{array}{c}207 \dagger \\
22\end{array}$ & $\begin{array}{l}1.35 \\
0.59\end{array}$ & $\begin{array}{l}3.66 \\
0.81\end{array}$ & 7 & $\begin{array}{r}322 \\
40\end{array}$ & $\begin{array}{l}2.00 \\
0.52\end{array}$ & $\begin{array}{l}5.00 \\
0.80\end{array}$ \\
\hline $5 \times 2$ & 10 & $\begin{array}{r}57 \\
3 \\
\end{array}$ & 5 & $\begin{array}{c}45 \dagger \\
5 \\
\end{array}$ & $\begin{array}{l}0.16 \dagger \\
0.05 \\
\end{array}$ & $\begin{array}{l}0.41 \dagger \\
0.23 \\
\end{array}$ & 2 & $\begin{array}{l}51 \dagger \\
13 \\
\end{array}$ & $\begin{array}{l}0.34 \dagger \\
0.21 \\
\end{array}$ & $\begin{array}{l}0.93 \dagger \\
0.38\end{array}$ & 3 & $\begin{array}{l}64 \dagger \\
22 \\
\end{array}$ & $\begin{array}{l}0.46 \dagger \\
0.28 \\
\end{array}$ & $\begin{array}{l}1.26 \dagger \\
0.53 \\
\end{array}$ & 3 & $\begin{array}{c}100 \dagger \\
28 \\
\end{array}$ & $\begin{array}{l}0.53 \dagger \\
0.39 \\
\end{array}$ & $\begin{array}{l}1.61 \dagger \\
0.77 \\
\end{array}$ & 2 & $\begin{array}{c}195 \dagger \\
63 \\
\end{array}$ & $\begin{array}{l}1.07 \dagger \\
1.09 \\
\end{array}$ & $\begin{array}{l}2.99 \\
2.03 \\
\end{array}$ & & animal & died & \\
\hline
\end{tabular}

* All data are mean values and SD. The dose of Cis-platin in $\mathrm{mg} / \mathrm{kg} \mathrm{BW}$; BW in g; GFR in $\mathrm{ml} / \mathrm{min}$; ERPF in $\mathrm{ml} / \mathrm{min}$

$\dagger p<0.05$ from control values. 
rats is almost proportionate to the retardation in growth. While the absolute GFR (ml/min) of young rats under treatment dropped well below that of controls, the GFR in relation to $\mathrm{BW}$ only fell below control values when the highest dose of Cis-platin was administered. Fractionated dosage reduced the initial renal damage in the adult rats, allowing for higher doses. Fractionation did not have that effect on the young animals, while it had hardly any effect on the permanent renal damage in either age group.

Apart from changes in renal function, both young and adult rats suffered from gastrointestinal toxicity immediately on drug administration. The animals became anorectic and particularly the higher dosage led to hemorrhagic diarrhea. It is not clear to what extent gastrointestinal toxicity and the resultant dehydration contributes to the deterioration in renal function and subsequent mortality in young rats. In the young rats the gastrointestinal complications rather than renal failure seemed to play a major part in the acute morbidity and mortality.

The nephrotoxicity of Cis-platin has been subject to extensive study, $(4,5,7,8,13,14)$; the exact mechanism is not yet clear. The morphologic, biochemical, and functional disarrangement is rather unspecific, and has also been observed after heavy metal poisoning $(7,15)$. Morphologically, renal damage is largely confined to the pars recta of the proximal tubule $(4-6,16)$. Despite the tubular location of the renal damage, the GFR still seems to

$\mathrm{GFR}(\mathrm{ml} / \mathrm{min} / 100 \mathrm{~g})$

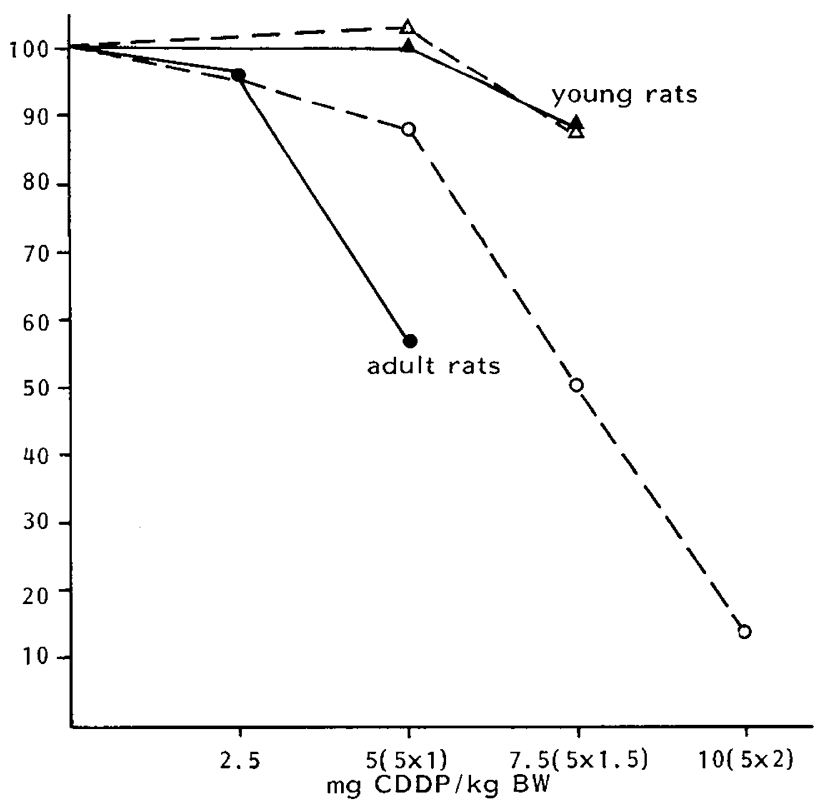

Fig. 2. Comparison of the permanent changes in GFR of either young or adult rats treated with Cis-platin. The GFR $(\mathrm{ml} / \mathrm{min} / 100 \mathrm{~g} \mathrm{BW})$ is given as a percentage of that of control rats, 15 wk after the first administration of Cis-platin. For symbols see legend of Figure 1. be a rather sensitive parameter to quantitate the nephrotoxicity (14). It cannot be excluded, however, that the measured GFR in fact underestimates the actual GFR, because of tubular backleak of the marker isotope (16). The decrease in GFR has also been attributed to the vasoconstriction of renal vessels by an activation of the renin-angiotensin system (7). Such an activation may be a direct effect of Cis-platin or function indirectly as a protective feedback mechanism, secondary to the excessive salt and fluid losses.

The difference in nephrotoxicity of Cis-platin in either young or adult rats is based on the difference in renal Pt concentration. Our analysis of the renal handling of $\mathrm{Pt}$ indicated that there was hardly any difference in the renal accumulation of Pt when comparing young and adult rats. Renal Pt excretion was also the same in young and adult rats after a dose of $5 \mathrm{mg} / \mathrm{kg} \mathrm{BW}$. After $7.5 \mathrm{mg} / \mathrm{kg} \mathrm{BW}$, the urinary Pt excretion was less efficient in the adult rats compared to the young rats. This might be due to the severe decline in renal function in the adult rats. The concentration of $\mathrm{Pt}$ in renal tissue, however, was significantly lower in young rats than in adult ones. This difference is due to the larger amount of renal tissue in relation to BW in the young rats (12). The magnitude of the Pt levels in renal tissue measured by us are comparable to those reported by others $(9,17)$. If Cis-platin nephrotoxicity is related to the Pt concentration in the kidney, the lower Pt levels found in the kidneys of young rats provide an explanation for the attenuated nephrotoxicity observed in these animals.

An attenuated nephrotoxicity in young rats is not a unique finding for Cis-platin. Similar results have been obtained comparing the nephrotoxicity of the aminoglycosides gentamicin and amikacin in young and adult rats. Both compounds when administered in dosages relative to $\mathrm{BW}$ were found to be less nephrotoxic in young rats. At the same time, despite a similar renal uptake, tissue aminoglycoside concentrations were found to be lower in these rats (18). Consequently, we surmised that drug-induced nephrotoxicity will generally be less in young than in adult rats, due to the larger amount of renal tissue relative to BW. In this respect it may be of importance that in humans, kidney weight relative to BW decreases with age (19).

In conclusion, when Cis-platin is administered in doses relative to BW this drug is less nephrotoxic in young rats than in adult rats. This reduction in nephrotoxicity is the result of the comparatively larger amount of renal tissue relative to body weight present in young rats.

Acknowledgments. The authors thank Mrs. A. Ribbink-Goslinga for her stylistic help and Mrs. T. Stehman for performing the Pt analyses at the Pediatric Research Lab of Sophia's Childrens Hospital (head: Prof. Dr. H. J. Degenhart).

\section{REFERENCES}

1. Baum ES, Gaynon P, Greenberg L, Krivit W. Hammond D 1979 Phase II study of Cis-dichlorodiammine-platinum (II) in childhood osteosarcoma. Children's Cancer Study Group Report. Cancer Treat Rep 63:1621-1626

2. Pratt CB, Hayes A, Green AA, Evans WE, Senzer N, Howarth CB, Ransom

Table 5. Renal handling of a single iv dose of 5 and $7.5 \mathrm{mg} / \mathrm{kg} \mathrm{BW}$ of Cis-platin in young and adult rats*

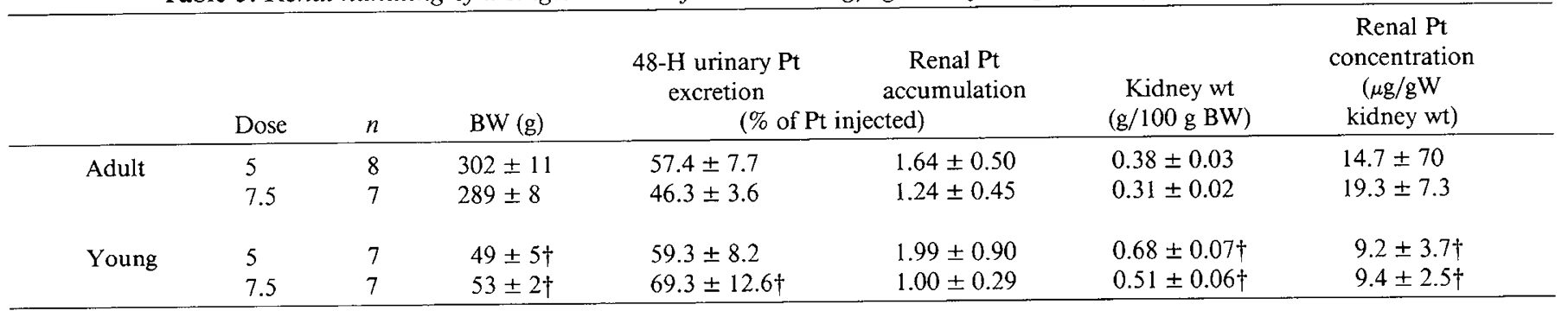

* All data are mean values $+\mathrm{SD}$.

$\dagger p<0.05$ when compared with the same dose in adult rats. 
JL, Crom W 1981 Pharmacokinetic evaluation of Cis-platin in children with malignant solid tumors; a phase 2 study. Cancer Treat Rep 65:1021-1026

3. Vietti TJ, Nitschke R, Starling KA, van Eys J 1979 Evaluation of Cisdichlorodiammineplatinum (II) in children with advanced malignant diseases; Southwest Oncology Group Studies. Cancer Treat Rep 63:1611-1614

4. Goldstein RS, Mayor GH 1983 The nephrotoxicity of Cis-platin. Life Sci 32:685-690

5. Ward JM, Fauvie KA 1976 The nephrotoxic effects of Cis-diamminedichloroplatinum (II) (NSC 119875) in male F344 rats. Toxicol Appl Pharmacol 38:535-547

6. Lippmann AJ, Helson C, Helson L, Krakhoff IH 1973 Clinical trials of Cisdiamminedichloroplatinum (NSC-119875). Cancer Chemother Rep 57:191-200

7. Madias NE, Harrington JT 1978 Platinum nephrotoxicity. Am J Med 65:307314

8. Prestayko AW, D'Aoust JC, Issell BF, Crooke ST 1979 Cis-platin (Cis-diamminedichloroplatinum II). Cancer Treat Rev 6:17-39

9. Harrison R. McAuliffe CA, Zaki A, Baer J. Sharma H, Smith A, Jackson H, Fox BW 1983 A comparative study of the distribution in the male rat of platinum labelled Cis-dichlorodiammine platinum (II), cis-trans-dichlorodihydroxy-bis (Isopropylamine) platinum (II), and cis-dichloro-bis-Cyclopropylamine platinum (II). Cancer Chemother Pharmacol 10:90-95

10. Pera MF, Zook, BC, Harder HC 1979 Effect of mannitol or furosemide diuresis on the nepohrotoxicity and physiological disposition of Cis-dichlorodiam- mineplatinum (2) in rats. Cancer Res 39:1269-1278

11. Kamalakar P, Freeman AI, Higby DJ, Wallace HJ, Sinks LF 1977 Clinical response and toxicity with Cis-dichlorodiammine platinum (II) in children. Cancer Treat Rep 61:835-839

12. Provoost AP, de Keyzer MH, Wolff ED, Molenaar JC 1983 Development of renal function of the rat. Renal Physiol 6:1-9

13. Guarino AM, Miller DS, Arnold ST, Pritchard JB, Davis RD, Urbanek MA Miller TJ, Litterst CL 1979 Platinate toxicity: past, present and prospects. Cancer Treat Rep 63:1475-1483

14. Stark JJ, Howell SB 1978 Nephrotoxicity of Cis-platinum (II) dichlorodiammine. Clin Pharmacol Ther 23:461-466

15. Levi J, Jacobs C, Kalman MS, McTigue M, Weiner MW 1980 Mechanism of Cis-platin nephrotoxicity: 1 Effect of sulfhydryl groups in rat kidneys. J Pharmacol Exp Therap 213:545-550

16. Chopra S, Kaufman JS, Jones TW, Hong WK, Gehr MK, Hamburger RJ, Flamenbaum W, Trump BF 1982 Cis-diamminmedichloroplatinum-induced acute renal failure in the rat. Kidney Int 21:54-64

17. Litterst CL, Torres IJ, Guarino AM 1976 Plasma levels and organ distribution of platinum in the rat, dog and dogfish shark following single intravenous administration of Cis-diamminedichloroplatinum(II). J Clin Hematol Oncol 7:169-179

18. Provoost AP, Adejuyigbe O, Wolff ED 1985 Nephrotoxicity of aminoglycosides in young and adult rats. Pediatr Res 19:1191-1196

19. Chantler C 1979 The kidney. In: Godfrey S, Baum JD (eds) Clinical Paediatric Physiology. Alden Press, Oxford, pp 356-398 